\title{
Erratum zu: Kunststoffe
}

\section{Erratum zu: \\ Kapitel 6 „Kunststoffe“ in: H. Briehl, Chemie der Werkstoffe https://doi.org/10.1007/978-3-662-63297-6}

Auf Seite 197 wurde in der zweiten Zeile der Reaktionsgleichung zwischen den Reaktionspartnern 88a ein Pluszeichen ergänzt. 